МЕТОДИ Й ФОРМИ ПІДГОТОВКИ ЗДОБУВАЧІВ ОСВІТИ ДО НАУКОВО-ДОСЛІДНИЦЬКОї ДІЯЛЬНОСТІ В УМОВАХ ДИСТАНЦІЙНОГО НАВЧАННЯ

\title{
METHODS AND FORMS OF PREPARATION OF STUDENTS FOR SCIENTIFIC-RESEARCH ACTIVITY IN THE CONDITIONS OF THE DISTANCE LEATNING
}

УДК 378.018.43:001.8 (045)

DOI https://doi.org/10.32843/2663$6085 / 2020 / 28.30$

\section{Краснова А.В.,}

студентка $\vee$ курсу фракультету дошкільної і спеціальної освіти та історії Комунального закладу «Харківська гуманітарно-педагогічна академія» Харківської обласної ради

\section{Ярославцева M.І.,}

канд. пед. наук,

доцент кафедри теорії та методики дошкільної освіти

Комунального закладу «Харківська гуманітарно-педагогічна академія» Харківської обласної ради

\section{Пехарєва С.В.,}

канд. пед. наук, доцент,

доцент кафедри теорії та методики дошкільної освіти

Комунального закладу «Харківська гуманітарно-педагогічна академія» Харківської обласної ради у статті розглянуто проблему використання методів і фрорм у підготовці здобувачі освіти до науково-дослідницької діяльності в контексті дистанційного навчання. Розкрито наукові підходи українських і зарубіжних студій до організації науково-дослідницької діяльності здобувачів освіти. Особлива увага приділена дистанційному навчанню, яке в роботі розглянуто як форма навчання, що дає можливість опрацьовувати зміст завдань академічних дисципліни за допомогою опосередкованої комунікації між викладачем і здобувачем освіти. Визначено методи організації наукової діяльності здобувачів освіти в процесі дистанційного навчання: дистанційне виконання завдань із науковотворчим складником у процесі вивчення профрільних дисциплін; самостійне опанування основ ведення наукових досліджень у процесі вивчення основи науково-дослідницькоі роботи студентів; активне залучення здобувачів освіти до дистаниійної гурткової та студійної роботи науково-творчого спрямування; заслуховування й обговорення результатів наукових досліджень здобувачів освіти на кафредральних он-лайн засіданнях $i$ семінарах. Запропоновані електронні платформи, які сприяють безперервній он-лайн комунікації між викладачами та здобувачами освіти. Визначено форми організації науково діяльності здобувачів освіти в прочесі дистанційного навчання: лекції та семінарські заняття на платорормах Zoom, Google Meet i Google class; дистанційні консреренції, семінари, вебінари, міжнародні лекції, фооруми; участь у Всеукраїнських конкурсах студентських наукових робіт; написання та захист випускних квалісфікаційних робіт. Педагогічна практика за дистанційними технологіями представлена як форма організації наукової діяльності здобувачів освіти, у процесі якої відбувається формування основних складників фрахової компетентності: спроможності визначати методологію дослідження, виокремлювати істотні зв'язки й відношення в процесі аналізу даних; володіти сучасними технологіями проектування та організації наукового дослідження. Досліджено ціннісні орієнтації студентів за адаптованою методикою М. Рокича, які сприяють активізачії науково-дослідницької діяльності в контексті дистанційного навчання.

Ключові слова: науково-дослідницька діяльність, дистанційна освіта, фрорми й методи підготовки до науково-дослідницької діяльності, здобувачі освіти.

The article considers the problem of using methods and forms in preparing students for research activities in the context of distance learning. Scientific approaches of Ukrainian and foreign studies on the organization of research activities of students are revealed. Particular attention is paid to distance learning, which in this work is considered as a form of learning that provides an opportunity to study the content of the tasks of academic disciplines through indirect communication between teacher and student. Methods of organization of scientific activity of students in the process of distance learning are determined: distance performance of tasks with scientific and creative component in the process of studying profile disciplines; independent mastering of the basics of conducting scientific research in the process of studying the discipline of the basics of research work of students; active involvement of students in remote group and studio work of scientific and creative direction hearing and discussion of the results of scientific research of students at the cathedral online meetings and seminars. Electronic platforms are proposed that promote continuous online communication between teachers and students. The forms of organization of scientific activity of students in the process of distance learning are determined: lectures and seminars on the platform Zoom, Google Meet and Google; remote conferences, seminars, webinars, international lectures, forums; participation in All-Ukrainian competitions of student scientific works; writing and defense of final qualifying works Pedagogical practice of distance technologies is presented as a form of organization of scientific activity of students, in the process of forming the main components of professional competence: the ability to identify methodological research, identify significant links and changes in the data analysis process; manage modern technologies of design and organization of scientific research. The value orientations of students are studied according to the adapted method of M. Rokeach, which promotes the intensification of research activities in the context of distance learning. Key world: scientific-research activity, distance education, forms and methods of preparation for research activities, students.
Постановка проблеми в загальному вигляді. Питання підготовки здобувачів освіти до науково-дослідницької діяльності було актуальним у всі часи. Завданнями сучасної вищої освіти $\epsilon$ створення умов для оволодіння фраховими компетентностями та підготовки такого педагога, який уміє креативно здійснювати професійну діяль- ність. У Концепції освітньої діяльності з підготовки здобувачів вищої освіти за другим рівнем вищої освіти (магістр) із спеціальності 012 Дошкільна освіта галузі знань 01 Освіта/Педагогіка зазначено зміст науково-дослідницької компетентності, яка $€$ одною $з$ основних фрахової компетентності: здатність виділяти актуальні проблеми розви- 
тку сучасної системи дошкільної освіти, спроможність визначати методологію дослідження, виокремлювати істотні зв'язки й відношення в процесі аналізу даних; володіти сучасними технологіями проектування та організації наукового дослідження на підставі комплексного підходу до вирішення проблеми профресійної діяльності; спроможність використовувати сучасні технології організації збору, оброблення даних і їх інтерпретації; критично оцінювати адекватність методів вирішення досліджуваної проблеми; розробляти та представляти обґрунтований перспективний план дослідницької діяльності; представляти науковому співтовариству дослідницькі досягнення у вигляді наукових статей, доповідей, мультимедійних презентацій відповідно до прийнятих стандартів і фрорматів профресійної спільноти. Отже, проблема підготовки майбутніх педагогів-науковців до профресійної діяльності є принципово-важливою та актуальною.

У 2020 році у зв'язку з епідемією Covid-19 гостро стало питання переведення освітнього процесу в дистанційну фрорму. Перед викладачами постало нове завдання - організувати заняття й інші види діяльності студентів так, щоб науководослідницька робота була продуктивною.

Для ефрективної організації науково-дослідницької діяльності здобувачів освіти в умовах дистанційного навчання необхідно правильно організувати роботу та підібрати відповідні методи й форми навчання. При грамотно організованому освітньому процесі науково-дослідницька діяльність здобувачів освіти повинна бути ефективною в будь-яких умовах.

Аналіз останніх досліджень і публікацій. Уважного ставлення дослідників останнім часом вимагає питання впровадження дистанційної освіти в процес підготовки здобувачів освіти до науково-дослідницької роботи.

Проблема розвитку дистанційної освіти $є$ досить актуальною, що підтверджує інтерес до неї протягом останніх десятиріч та аналіз даних Scopus, Web of Science, Google Scholar, Google Trends тощо.

Особливості спілкування в умовах дистанційного навчання висвітлюються в працях В. Баженової, П. Маркова. Наукові студії В. Поруса, В. Самохвалової займалися проблемами фрілософії науки. Мотиваційний аспект наукової діяльності здобувачів освіти розглядали в працях О. Глущенко, Т. Калашникова, А. Козлов, М. Матушкін, 3. Сазонова та ін.

Питанням фрормування активної пізнавальної діяльності, що лежить в основі розвитку й удосконалення різних аспектів дослідницьких умінь здобувачів освіти, приділено увагу наукових студій (Л. Аврамчук, Т. Алексєєнко, В. Андрєєв, П. Лузан, А. Дьомін, В. Рябець, П. Олійник).
Дослідження науково-дослідницької діяльності здобувачів освіти висвітлено в наукових доробках учених на сучасному етапі розвитку освіти у вищій школі (О. Жерновникової, Л. Калашнікової, М. Роганової, А. Чаговець, Х. Шапаренко та ін.). Загальні питання організації науково-дослідницької роботи здобувачів освіти розглядалися в працях С. Гончаренка, А. Кушнірук, Д. Пойя, В. Прошкіна, С. Ракова, О. Скафи, В. Шахова й ін.

М. Князян здійснила аналіз зарубіжного досвіду 3 проблеми організації науково-дослідницької діяльності студентів. Такими, що викликають інтерес у системі вищої педагогічної освіти США й Канади, є такі види самостійної дослідницької діяльності, як складання портороліо, написання етнічної автобіографії, есе, доповідей, створення проектів, організація аутентичних бесід і публічних презентацій, використання «кейсів», робота 3 «підготовленими питаннями», що загалом забезпечують системність і систематичність інтеріоризації фахових знань, рефлексивних і дослідницьких умінь майбутніх спеціалістів. У країнах Західної Європи в організації самостійно-дослідницької діяльності значна увага приділяється системному зв'язку теорії та практики, виробленню в студентів у ході самостійної дослідницької діяльності критичних суджень, власної позиції. Тому в професійній підготовці домінують інтерактивні, дискусійні, креативні форми, що віддзеркалюють особистісну позицію та досвід студента, дають змогу встановити партнерські стосунки як усередині групи, так і між здобувачами освіти й викладачем. Самостійно-дослідницька робота пронизує більшість навчальних тем у зарубіжній вищій школі, що сприяє, за оцінками дослідників такого досвіду, цілісності підготовки фрахівця безперервної самоосвіти впродовж життя [10].

Виділення не вирішених раніше частин загальної проблеми. Підготовка здобувачів освіти до науково-дослідної діяльності була завжди однією з найпріоритетніших цілей у системі вищої освіти. Останнім часом гостро постало питання організації освітнього процесу в дистанційній фрормі, доцільного підбору методів і прийомів навчання на відстані. На жаль, структура організації дистанційної освіти в Україні ще не досконала та потребує вдосконалення.

Мета статті полягає в дослідженні процесу підготовки здобувачів освіти до науково-дослідницької діяльності в умовах дистанційного навчання. Завданнями статті $€$ аналіз наукових підходів до проблеми організації науково-дослідницької діяльності студентів; визначення методів і форм організації наукової діяльності здобувачів освіти на електронних платорормах; дослідження ціннісних орієнтацій студентів, які сприяють активізації науково-дослідницької діяльності в контексті дистанційного навчання. 
Виклад основного матеріалу. Науководослідницька діяльність $є$ одним із найважливіших засобів підвищення рівня підготовки й виховання здобувачів освіти, здатних творчо та ефрективно застосовувати в практичній діяльності найновіші досягнення науково-технічного прогресу. Відповідно до першої статті Закону України «Про наукову і науково-технічну діяльність» [4], наукова діяльність - це інтелектуальна творча діяльність, спрямована на одержання й використання нових знань. Основними формами наукової діяльності є фундаментальні та прикладні наукові дослідження. У Законі України «Про вищу освіту» [6] зазначається, що наукові товариства студентів популяризують наукову діяльність серед студентської молоді, сприяють залученню осіб, які навчаються, до наукової роботи та інноваційної діяльності.

У статті 9 «Форми здобуття освіти» Закону України «Про освіту» зазначається, що дистанційна фрорма здобуття освіти - це індивідуалізований процес здобуття освіти, який відбувається в основному за опосередкованої взаємодії віддалених один від одного учасників освітнього процесу в спеціалізованому середовищі, що функціонує на базі сучасних психолого-педагогічних та інформаційно-комунікаційних технологій [5].

У 2020 році у зв'язку з епідемією COVID-19 в Україні та світі актуальною стало питання організації педагогічного процесу в дистанційній фрормі. Дистанційне навчання - це сукупність технологій, що забезпечують надання здобувачам освіти основного обсягу наукового матеріалу, інтерактивну взаємодію між здобувачами освіти й викладачем у процесі навчання, надання здобувачам освіти можливості самостійно працювати 3 навчальним матеріалом [2].

К. Крутій зазначає, що фрорма навчання заочна, дистанційна - це зовнішня організація начальнопізнавального процесу, яка здійснюється без відриву від виробництва, але заняття зі здобувачами освіти проводяться в сесійному порядку кілька разів упродовж навчального року, як правило, два рази на кожний семестр [3].

У роботі дистанційне навчання розглядаємо як фрорму навчання, що дає можливість опрацьовувати зміст завдань академічних дисципліни за допомогою опосередкованої комунікації між викладачем і здобувачем освіти.

В умовах дистанційного навчання особливої значущості набувають такі методи організації наукової діяльності здобувачів освіти, а саме: дистанційне виконання завдань 3 науково-творчим складником у процесі вивчення профрільних дисциплін; самостійне опанування основ ведення наукових досліджень у процесі вивчення дисципліни основи науково-дослідницької роботи студентів; створення навчально-наукових структур для поза- аудиторного навчання й активне залучення здобувачів освіти до дистанційної гурткової та студійної роботи науково-творчого спрямування; заслуховування й обговорення результатів наукових досліджень здобувачів освіти на кафедральних он-лайн засіданнях і семінарах [8].

За допомогою вищезазначених методів студенти набувають уміння аналізувати результати наукових досліджень, застосовувати їх при вирішенні конкретних науково-дослідницьких завдань; самостійно здійснювати науковий пошук, спираючись на індивідуальні дослідницькі здібності.

Ефективність проведення наукової діяльності під час карантину залежить від умов, які створює адміністрація вишу та викладачі. При організації дистанційного навчання викладачі можуть скористуватися такими електронними платформами: Google class, Zoom, Google Meet, Skype. Для ефективної та безперервної комунікації з аудиторією можна створювати спільні чати в платформах Viber, Telegram, WhatsApp тощо. При створенні тестових завдань педагоги мають можливість звернутися до таких платформ, як Classtime, Kahoot, Quzizz, IDroo, Miro.

Підвищити рівень вивчення іноземної мови, удосконалити свої педагогічні навички, здобути досвід наукової роботи й отримати сертифрікат про проходження того чи іншою он-лайн курсу можна на таких інтернет-платорормах, як EdEra; edX; Coursera; Khan Academy; Відкритий Університет Майдану; Codecademy; Duolingo; Lingva. Skills тощо.

Під час дистанційного навчання доречно проводити такі фрорми роботи: лекції та семінарські заняття на платформах Zoom, Google Meet i Google class; дистанційні конореренції, семінари, вебінари, міжнародні лекції, форуми; участь у Всеукраїнських конкурсах студентських наукових робіт; написання та захист випускних кваліфікаційних робіт. У процесі цих фрорм роботи здобувачі освіти можуть користуватися навчально-методичним комплексом дисциплін електронної бібліотеки вищу, отримувати інфрормацію з профрільних дисциплін у дистанційній формі.

Здобувачам освіти випускних курсів рекомендовані різноманітні освітні он-лайн платорорми, де вони мають змогу пройти семінари з отриманням сертифріката. Так, сучасні он-лайн платформи пропонують такі курси та вебінари: «Глобальне тестування на Національній он-лайн платформі з цифрової грамотності»; «Вступ до критичного мислення»; «Креативне мислення»; «Академічна доброчесність в університеті»; «Запобігання торгівлею людьми»; «Екологічні дати року. Що? Де? Як? Коли?»; «Участь батьків в організації інклюзивного навчання», «Методики інтелектуального розвитку дошкільника. Блоки Дьонеша, Палички Кюізенера, «Шість дарів Фребеля, кола Ейлера», 
«Путівник в умовах карантину: діти, батьки, заклад дошкільної освіти», «Медійна грамотність в освітньому процесі», «Цисррова грамотність: YouTube, Gmail, Google Диск. Інтеграція сучасних застосунків у Блог і Тести на «Всеосвіті» тощо.

Однією 3 форм підготовки здобувачів освіти до науково-дослідницької діяльності $€$ виробнича та педагогічна практика за дистанційними технологіями. У процесі практики відбувається процес формування в практикантів основних складників фахової компетентності, а саме: спроможність визначати методологію дослідження, виокремлювати істотні зв'язки й відношення в процесі аналізу даних; володіти сучасними технологіями проектування та організації наукового дослідження.

Під час проведення он-лайн занять із дітьми, он-лайн діагностики дітей і батьків, студенти набувають таких морально-вольових якостей: відповідальність, самостійність, дисциплінованість, обов'язковість, організованість. Саме ці якості сприяють фрормуванню індивідуально-дослідницьких здібностей, які є основою дослідницької діяльності. За результатами практики доречно організувати звітну он-лайн конференцію на платформі Zoom, де обговорити питання, пов'язані з особливостями проходження практики за дистанційними технологіями.

3 метою дослідження ціннісних орієнтацій студентів, які сприяють активізації науково-дослідницької діяльності в контексті дистанційного навчання на базі Комунального закладу «Харківської гуманітарно-педагогічної академії» Харківської обласної ради проведено он-лайн дослідження за адаптованою методикою «Ціннісні орієнтації» М. Рокича [7]. Дослідження проводилося протягом квітня-червня 2020 року, у ньому брали участь здобувачі освіти 2-5 курсів фракультету дошкільної і спеціальної освіти та історії напряму підготовки 012 Дошкільна освіта. Загалом опитано 98 осіб.

Учасникам дослідження було запропоновано два списки цінностей - термінальних та інструментальних (по 9 цінностей у кожному), записаних у довільному порядку. Ранжування структури термінальних та інструментальних цінностей $€$ додатковим способом визначення рівня готовності здобувача освіти до науково-дослідницької діяльності. Залежно від того, які саме цінності є пріоритетними, можна зробити висновок про готовність/ неготовність майбутнього фрахівця дошкільної освіти до науково-дослідницької діяльності, самопізнання, ступінь розвитку його рефлексивних навичок.

Порівняльний аналіз відповідей студентів показує, що верхню диспозицію в структурі термінальних цінностей посідають професіоналізм, компетентність педагога; інтерес до дослідницької діяльності, допитливість; відповідальність
(71 опитуваних, що становить 69,6\%). При цьому значення таких цінностей, як професіоналізм і компетентність, підвищуються на третіх курсах (62 опитуваних, що становить 60,8\%) і посідають перше положення на п'ятому (78 респондентів, що становить 76,4\%). Важливим $€$ те, що більшість опитаних здобувачів освіти (86 опитуваних, що становить 84,3\%) виділяють як головні освітні цінності такі: дисциплінованість, відповідальність, освіченість, упевненість у собі. Такі відповіді характеризують готовність здобувачів освіти до наукової діяльності. Стабільне місце в середині таблиці посідає цілеспрямованість (48 опитуваних, що становить 47,04\%), що свідчить про розуміння важливості професійного зростання науковця. Недостатньо високо (22 опитуваних, що становить 21,6\%) оцінюється така важлива якість особистості педагога, як самоконтроль. Лише здобувачі 4 курсу визнають духовний розвиток і роботу над собою настільки важливою, що відводять їм четверте рангове місце. Такі цінності, як суспільне визнання, авторитет науковця та матеріальний достаток, не входять до престижних і посідають останні місця в ієрархії цінностей у всіх опитаних (12 опитуваних, що становить $11,8 \%$ ).

Високо оцінюються освіченість, вихованість, терпіння (69 респондентів, що становить 67,6\%). Середню позицію структури цінностей (54\%) представляють такі важливі якості науковця, як широта поглядів (уміння зрозуміти іншого), відповідальність (почуття обов'язку, уміння дотримуватися свого слова), вихованість та інтелігентність - той образ дій, якому віддають перевагу в педагогічному процесі. Достатньо високо оцінюють здобувачі вимогливість до себе й оточуючих (54 опитуваних, що становить 52,9\%). Розглядаючи динаміку цієї якості за курсами, можемо зазначити, що ії значущість має тенденцію до зниження на 2 і 3 курсах (46 опитуваних, що становить 45,1\%) і підвищення на випускному курсі (54 опитуваних, що становить 52,9\%), що характеризує рівень професійної зрілості. Серед інструментальних цінностей останню диспозицію посідає самоконтроль, дещо підвищуючись до 4 курсу (24 респондентів, що становить 23,5\%) і більше виявляючись на 5 курсі (34 опитуваних, що становить 33,3\%).

Можна зробити висновок, що зміни в структурі цінностей - засобів професійної життєдіяльності в здобувачів освіти, які навчаються на різних курсах, зумовлені практичною спрямованістю їхньої діяльності, інтеграцією окремих особистісних якостей у наукову спрямованість. Зміна цінностей, що становлять структуру науково-профресійної діяльності, є вираженням самопізнання здобувача освіти себе як майбутнього фахівця в науково-дослідній діяльності, вироблення власного наукового погляду. Аналізуючи результати дослідження, можна дійти висновку, що в здобу- 
вачів освіти поступово починають фрормуватися потреби в науковій діяльності, тобто мотиваційна сорера. Так, виникнення мотивів, що пов'язані 3 напрямами науково-дослідницької діяльності, стають рушійної силою для виникнення в здобувачів освіти бажання бути самореалізованими в науковій діяльності.

Зазначимо, що завдяки відповідним фрормам і методам роботи в здобувачів освіти перших курсів починає фрормуватися інтерес до науково-дослідницької діяльності. Підготовка здобувача освіти до науково-дослідницької діяльності в закладах вищої освіти має проводитися безперервно, систематично й послідовно.

Висновки. У роботі проаналізовано наукові підходи до проблеми організації науково-дослідницької діяльності студентів; визначено методи та форми організації наукової діяльності здобувачів освіти на електронних платорормах; досліджено ціннісні орієнтації студентів, які сприяють активізації науково-дослідницької діяльності в контексті дистанційного навчання. Подальших наукових розвідок потребує питання створення міжнародних наукових гуртків за участі студентів і викладачів закладів вищої освіти в режимі он-лайн за дистанційними технологіями.

\section{БІБЛІОГРАФІЧНИЙ СПИСОК:}

1. Власенко Л.В. Методи дистанційного навчання. Софрія, 2011. Т. 19. С. 16-20.
2. Войтко В.В. Форми і методи залучення студентів до наукової творчості Матеріали XLV науково-технічної конореренції підрозділів Вінницького національного технічного університету (НТКП ВНТУ-2016) : збірник доповідей. Вінниця : ВНТУ, 2016.

3. Дошкільна освіта : словник-довідник : понад 1000 термінів, понять та назв / упор К.Л. Крутій, О.О. Фунтікова. Запоріжжя : ТОВ «ЛІПС» ЛТД, 2010. 324 с.

4. Про наукову і науково-технічну діяльність : Закон України від 26.11.2015 № 848-VIII / Верховна Рада України. Відомості Верховної Ради України (BBP). 2016. № 3.25 c. URL: https://zakon.rada.gov.ua/ laws/show/848-19 (дата звернення: 27.09.2020).

5. Про освіту : Закон України. Освіта в Україні. Нормативна база. 2-е вид. Київ : КНТ, 2006.

6. Про вищу освіту : Закон України. Відомості Верховної Ради України. 2019. № 243-VIII. URL: https://zakon.rada.gov (дата звернення: 28.09.2020).

7. Киселева А.В. О возможности модисрикации методики М. Рокича «Ценностные ориентации». Психологическая диагностика. Москва, 2004. № 4. C. 101.

8. Корбут О.Г. Дистанційне навчання: моделі, технології, перспективи. URL: http://confesp.fl.kpi.ua/ru/ node/1123 (дата звернення: 04.10.2020).

9. Методика викладання у вищій школі : навчальний посібник / О.В. Малихін, І.Г. Павленко, О.О. Лаврентьєва, Г.І. Матукова. Київ : КНТ, 2014. 262 с.

10. Kniazian M.O. Systema formuvannia samostiinodoslidnytskoi diialnosti maibutnikh uchyteliv inozemnykh mov u protsesi. Вісник ЛНУ імені Тараса Шевченка. 2007. Ч. II. № 6 (329). 